\title{
CRIMINAL POLICY IN THE MANAGEMENT OF ROAD TRAFFIC ACCIDENTS
}

Yulius Harya PAMUNGKAS, PhD. C. (D) 1*

Moch. BAKRI (iD) 2

Prija DJATMIKA (iD) 3

Rachmad SAFA'AT (iD 4

1 Brawijaya University, Faculty of Law, Doctoral Study Program, yulius.fhub@gmail.com *Correspondent Author.

2 Brawijaya University, Faculty of Law, bakri@ub.ac.id

3 Brawijaya University, Faculty of Law, prija.djatmika@ub.ac.id

4 Brawijaya University, Faculty of Law, rachman.safaat@ub.ac.id

\begin{tabular}{ll}
\hline $\begin{array}{l}\text { Article history: } \\
\text { Accepted } 30 \text { July } 2020 \\
\text { Available online } 31 \text { August } 2020\end{array}$ & Acceleration in modern life requires acceleration, including acceleration on the highway. The \\
& accumulation of interests that are centralized on this highway creates a conflict of interest that ends \\
Keywords: & in material loss or loss of life. Many road users do not realize that the legal consequences of \\
Criminal Policy, & negligence are categorized as criminal acts because they cause others to suffer. Legal politics the \\
Road Traffic Accident, & issuance of Law Number 22of 2009 concerning Road Traffic and Transportation as an embodiment \\
Management. & of criminal policy to provide legal protection and legal certainty for citizens who are casualties of \\
& road traffic accidents. Through criminal policy, it is expected that there will be order, smoothness, \\
& security in road traffic and legal certainty and legal protection for road users.
\end{tabular}

\section{Introduction}

Road Traffic and Transport is the pulse of the national economy and plays a very strategic role in realizing development and public welfare. This is in line with the aspirations of the Indonesian people contained in the opening of the 1945 Constitution of the Republic of Indonesia. The progress of modern transportation supported by well-ordered roads has certainly had an impact on economic development. The increase in the economy has an impact on changes in human life, where everyone has a target of work and time, which requires high mobility, this condition makes everyone use the road in order to fullfill these things.

The number of road users on the highway, resulting in conflicts of interest on the highway, so that the behaviour of drivers can be varied, ranging from improper parking, breaking red lights, breaking signs, violating road markings, and the most dangerous is a traffic accident road that brings casualties.
So far, the public has not been aware that traffic violations are a type of crime, so that many do violations, and their understanding is limited to being ticketed and paying fines if caught by traffic officers. Sudarto, as quoted by Suhariyono (2012), said that crime is "suffering that is deliberately inflicted on people who commit acts that meet certain conditions". In another book, Sudarto said: "that traditional crime is defined as the misery that is imposed by the state on someone who violates the provisions of the law". According to Moeljanto as quoted in Eddy O.S Hiariej (2016), criminal law is a part of the entire applicable law in a country, which establishes the basics and regulates the provisions of acts that must not be done, prohibited accompanied by criminal threats for those who commit them. When, and in what cases, those who have violated the prohibition, may be subject to criminal sanctions and in what way criminal prosecution can be carried out.

Law Number 22 of 2009 Concerning Road Traffic and Transportation, is a formal legal product in regulating order, smoothness so that the implementation of Traffic and Road 
Transportation can be carried out safely, securely, orderly, smoothly, and efficiently. This law regulates criminal sanctions for people who commit acts on the road, which results in disorder, non-smoothness and threatens the safety of others.

The provisions of criminal provisions for motorists in Law Number 22 of 2009 concerning Traffic and Road Transportation are regulated in Chapter XX concerning Criminal Provisions, which from articles 273 to article 315 regulates the amount of fines and criminal penalties for everyone who uses the road.

Criminal arrangements in the provisions of this Law are divided into 2 (two) groups, namely groups of violations and criminal groups. The determination of violation groups and crime groups is regulated in article 316 , which states, namely:

(1) "The provisions referred to in Article 275, Article 275 paragraph (1), Article 276, Article 278, Article 279, Article 280, Article 281, Article 282, Article 283, Article 284, Article 285, Article 286, Article 287 , Article 288, Article 289, Article 290, Article 291, Article 292, Article 293, Article 294, Article 295, Article 296, Article 297, Article 298, Article 299, Article 300, Article 301, Article 302, Article 302, Article 302, Article 303, Article 304, Article 305, Article 306, Article 307, Article 308, Article 309 and Article 313 are violations".

(2) "The provisions referred to in Article 273, Article 275 paragraph (2), Article 277, Article 310, Article 311 and Article 312 are crimes."

In dividing the two groups of criminal acts above, it is clear that the political law on the establishment of Law Number 22 of 2009 concerning Road Traffic and Transportation, is to impose financial penalties and criminal penalties for everyone who interferes with KAMTIBCARLANTAS (Security, Orderly and Traffic Smoothness); it is intended that every person who uses the road, get legal protection and certainty by the state.

In writing this research, the author will discuss criminal law policies on road traffic accidents. The discussion in this study was carried out with a theoretical and empirical approach. Further discussion is described in the following chapter.

\section{Research Method}

Research is a way of developing science and technology. Research aims to reveal the truth systematically, methodologically and consistently through the research process. In this research method, normative legal research is used, or also called library legal research, which is legal research conducted by examining primary legal materials and secondary data or library materials. In this study, the approaches used by researchers to address the issue of legal issues is Law Approach. The approach to the law is to examine all laws and regulations relating to the legal issues being examined. With this approach, consistency and compatibility between one Law and other Laws or the Laws with the Basic Law or between regulations and laws will be known so that the benefits in providing legal certainty and justice will be known.

To be able to answer the issue of legal issues, researchers need research sources in the form of primary and secondary legal materials. Primary legal material is legal material consisting of legislation, official records or minutes in the making of laws, and judges' decisions. Secondary legal materials are all legal publications which are official documents such as textbooks, legal dictionaries, legal journals and comments on court decisions, which are still related to research material. The legal materials that have been obtained are then administered, compiled, recorded, edited, studied, and extracted, then the materials are examined in accordance with the problem set. Primary and secondary legal materials that have been collected, then analyzed and examined, the results of the analysis and study of primary and secondary legal materials become a clue as an answer to the legal problems of this study.

\section{Results and Discussion}

\subsection{Road Traffict Accident Crimes}

The development of automotive technology that creates modern transportation, on the one hand increases the standard of living of people in mobility, but on the other hand, the frequency of the number of risk of accidents in the use of motorized vehicle transportation has resulted in the number of human lives that are very numerous each year.

The number of traffic accident casualties recorded by the National Police Traffic Corps from 2013 to 2015 is relatively large, with an average of 160,000 fatalities per year. In 2017, PT Jasa Raharja (Persero) recorded 121,805 casualties due to traffic accidents. This number is dominated by productive age, which means that many workers have become casualties, which results in other social problems, namely: poverty, displaced children, increasing disability population (disability due to accidents), school dropouts, theft and others. According to Kun Wahyu Wardana (2009), the impact of road traffic accidents on casualties stated, "That the casualties of road traffic accidents who died in 2006 were 36,000 casualties, which affected $62.5 \%$ of the families they lived in being poor, besides that the social and psychological impacts must have been far more serious, when the fate of a wife 
became a widow or children who have been orphaned by the death of their parents".

Hikmanto Juwana (2016), stated, the impact of the impact of road traffic accidents has a social impact, namely: "In the context of traffic accidents, socio-economic risks which are unavoidable. From a traffic accident, a person can lose his physical ability to do his daily work, so the family left will lose the backbone of the family".

There are factors causing the occurrence of road traffic accidents resulting in the fall of fatalities on the highway caused by various factors. The factors causing these are:

Individual Awareness Factor, this factor determines the risk of accidents, the higher awareness in traffic, the number of traffic accidents will decrease.

Infrastructure Factors, this factor is the cause of accidents, namely if many roads are damaged and potholes, it can result in accidents and casualties.

Negligence Factors of Apparatus or Officers, if the officer assigned to regulate the traffic flow is negligent, resulting in an accident. An example is a train door guard who is negligent in closing a train door when a train is passing which results in an accident.

Vehicle Maintenance Factors, vehicles that are not cared for properly have the potential to cause accidents, this occurs because vehicle components that are not suitable for use are still forced to use, so they do not function properly which results in accidents (Wardana, 2009).

In an effort to prevent road traffic accidents resulting in casualties, the factors that cause accidents must be prevented and anticipated in order to protect other road users to create KAMTIBCARLANTAS on the highway, then the enactment of Law Number 22 of 2009 concerning Traffic and Transportation Roads, forcing everyone not to be the cause of road traffic accidents by avoiding and eliminating the factors causing the accidents above. Coercion to road users so as not to be the cause of road traffic accidents is effectively done by giving criminal sanctions to everyone who is the perpetrators of road traffic accidents resulting in casualties or material losses. Criminal provisions in accordance with Law Number 22 of 2009 for perpetrators causing road traffic accidents resulting in losses for other parties are contained in the following articles:

\section{a. Article 230:}

"The Traffic Accident Case as referred to in article 229 paragraph (2), paragraph (3) and paragraph (4) is processed by a criminal justice program in accordance with the provisions of the legislation."

b. Article 310:

(1) "Every person who drives a Motorized Vehicle due to their negligence resulting in a Traffic Accident with damage to the Vehicle and / or goods as referred to in Article 229 paragraph (2), sentenced to a maximum imprisonment of 6 (six) months and / or a maximum fine of Rp 1,000.000.00 (one million rupiah)."

(2) "Every person who drives a Motorized Vehicle due to their negligence results in a Traffic Accident with casualties of minor injuries and damage to the Vehicle and / or goods as referred to in Article 229 paragraph (3), sentenced to a maximum imprisonment of 1 (one) year and / or a fine a maximum of Rp. 2,000,000.00 "(two million rupiah)."

(3) "Every person who drives a Motorized Vehicle due to his negligence resulting in a Traffic Accident with a heavy injury casualties as referred to in Article 229 paragraph (4), sentenced to a maximum imprisonment of 5 (five) years and / or a maximum fine of $\mathrm{Rp}$ 10,000,000, 00 (ten million rupiah).”

(4) "In the case of an accident as referred to in paragraph (3) which results in the death of another person, sentenced to a maximum imprisonment of 6 (six) years and / or a maximum fine of Rp 12,000,000.00 (twelve million rupiah).”

The imposition of criminal penalties for perpetrators who cause road traffic accidents as regulated in article 310 paragraph (1), paragraph (2), paragraph (3) and paragraph (4), is a criminal act (see article 316 paragraph 2). This means that the handling and prevention of road traffic accidents must be a priority to reduce the number and provide a law for the perpetrators.

Other technical arrangements for road traffic violations with criminal law are regulated technically in the Regulation of the Head of the Indonesian National Police Number: 15 of 2013 concerning Procedures for Handling Traffic Accidents, in article 38 states: "The procedure for investigating traffic accidents is carried out in accordance with the Criminal Procedure Act and the provisions of the legislation".

The nature of the above criminal sanctions is to provide protection to other citizens in traffic so that secure, safe, orderly, smooth and integrated road traffic is integrated with other modes of transportation to encourage the national economy, promote public welfare, strengthen the unity and integrity of the nation and able to uphold the nation's dignity as well as the realization of 
cultured traffic ethics with the goal of manifesting law enforcement and legal certainty for the people.

\subsection{Criminal Law Policy in Road Traffict Accidents}

Before discussing the criminal law policy in road traffic accidents, it is necessary to discuss the function of criminal law and criminal purposes. The function of criminal law according to Sudarto as quoted from Eddy O.S. Hiariej (2016), stated that the criminal law function is divided into two namely general functions and special functions. The general function of criminal law is the same as the function of law in general, namely to regulate social life or conduct order to the people, while the special function of criminal law is to protect the legal interest against acts that want to rape them with sanctions in the form of crime.

Criminal objectives are broadly divided into three, namely absolute theory, relative theory and joint theory. Each of these theories is:

1. Absolute Theory, according to this theory retaliation is the legitimacy of punishment. The state has the right to impose a criminal offense because criminals have committed attacks and rapes on protected legal rights and interests. This theory is also called the theory of retaliation.

2. The Relative Theory, according to this theory, punishment is for the enforcement of public order and the criminal goal is to prevent crime.

3. Combined theory, according to Vos, this theory aside from focusing on retaliation, the purpose of the nature of retaliation is needed to protect law order. Vos has given equal weight between retaliation and people protection (Hieariej, 2016).

Crime mitigation is not only in the aspect of criminal provision as absolute theory, relative theory and joint theory, but efforts and policies to make good criminal law regulations are essentially inseparable from the purpose of crime prevention, this is called a penal policy or criminal law policy. According to Muladi and Barda Nawawi Arief (2010) law enforcement is an embodiment of a criminal sanction as a process of embodying policy. The policy in this case is a criminal law policy consisting of three stages to produce a rational form of law enforcement, namely:

1. Stages of determining the penalty by the legislator;

2. The sentence decision stage, by the court; and

3. The execution stage of the sentence by the first execution apparatus.
The handling of road traffic accidents if referring to criminal law policy theory, must be started from the first stage, namely the stipulation in the making of laws, this is interpreted at the time of making the Law on Road Traffic, must contain sociopolitical, and sociocultural values; which underlies and gives content to the normative and substantive content of the idealized criminal law, so that the "spirit" of the law really provides a sense of justice in accordance with the culture of its users, which in turn the implementation of this law becomes effective and the people will be orderly traffic on the highway. At this stage the legislator, namely the House of Representatives (DPR) and the President must be well aware that the law has a position as a rule of the game for the people to consolidate their political and legal position, to regulate life together in order to realize the goals in the form of the state. The law can also be said as a collection of principles governing government power, people's rights, and the relationship between the two. For this reason, the seriousness of the House of Representatives and the Government / President in the formation of laws starting from the preparatory stage, the discussion up to the ratification that is believed to be only in the interests of the people, not for personal or group interests, so that after being implemented it can be effective and able to create order and prevent violations and law enforcement.

In the second stage, namely the granting or imprisonment by the court, then at this stage every road user who causes a road traffic accident resulting in fatalities and material losses must be subject to criminal penalties, in order to obtain legal certainty and legal protection for the casualties. According to Zainal Arifin Hoesein (2016), The judiciary as an independent and authoritative state power is idealized to be able to carry out its functions. These functions include:

1. As a pressure valve, which means the authority granted by the constitution and laws through the judicial bodies to suppress any action that is contrary to the law, by giving punishment to anyone and any party who commits an unconstitutional violation, namely a violation which is contrary to public order and that violates propriety (violation with the reasonableness).

2. As ultimum remedium, which means as the last place in seeking and upholding truth and justice.

3. As the guardian of people's independence (the guardian of citizens' constitutional rights and human rights), which means that judicial institutions must be able to prioritize the constitutional rights of citizens and human rights. 
4. As the trustee of the people (judiciary are regarded), meaning that the power of the judiciary is a place of protection and restoration of the original situation for the people who feel violated or disadvantaged by the interests of individuals, groups, and even by the authorities.

5. Court decisions are like the decisions of God Implementation of the functions of judges in court decisions in handling road traffic accident cases which the author can convey below is in the form of road traffic accident cases from Tangerang City District Court, where the judge's role in deciding his case considers and promotes justice for the perpetrators and casualties, as follows:

(Judicium Die), this happens as a consequence of the free and independent principles given by the constitution and laws to the judiciary.

Table 1. The Judge's Decision of Road Traffic Accident Cases From Tangerang City District Court

\begin{tabular}{|c|c|c|c|c|c|}
\hline NO & DECISION & $\begin{array}{l}\text { DEFENDANT'S } \\
\text { NAME }\end{array}$ & $\begin{array}{l}\text { CHRONOLOGY OF } \\
\text { ACCIDENT }\end{array}$ & $\begin{array}{ll}\text { NUMBER } & \text { OF } \\
\text { CASUALTIES } & \end{array}$ & $\begin{array}{l}\text { JUDGE'S } \\
\text { DECISION }\end{array}$ \\
\hline 01 & $\begin{array}{l}1260 \text { / Pid.Sus / } \\
2015 \text { / PN Tng } \\
25 \text { August } 2015\end{array}$ & Irman Ariz bin Suprapto & $\begin{array}{l}\text { Defendant is a car driver } \\
\text { who crashed into } 2 \text { (two) } \\
\text { motorcycle riders so that } \\
\text { they were injured }\end{array}$ & $\begin{array}{l}3 \text { (three) people were } \\
\text { injured and treated in } \\
\text { the hospital. }\end{array}$ & $\begin{array}{l}\text { Criminal } \\
\text { imprisonment for } 1 \\
\text { (one) year and a } \\
\text { fine of Rp. } \\
1,000,000,- \\
\text { a subsidiary of } 1 \\
\text { month in prison }\end{array}$ \\
\hline 02 & $\begin{array}{l}\text { 590 / Pid.Sus / } \\
\text { 2016/ PN.TNG } \\
\text { 22 June } 2016\end{array}$ & Sugandi Bin Armawi & $\begin{array}{l}\text { Defendant is a motorcycle } \\
\text { driver in the opposite } \\
\text { direction and then crashed } \\
\text { into another motorcycle } \\
\text { resulting in serious injuries }\end{array}$ & $\begin{array}{l}1 \quad \text { (one) seriously } \\
\text { injured person }\end{array}$ & $\begin{array}{l}\text { Criminal } \\
\text { imprisonment for } 1 \\
\text { (one) year }\end{array}$ \\
\hline 03 & $\begin{array}{l}336 \text { / Pid.Sus / } \\
\text { 2018 / PN.Tng } \\
\text { 19April } 2018\end{array}$ & $\begin{array}{l}\text { Gugun Gunardi } \text { bin } \\
\text { Gaston Kusnadi }\end{array}$ & $\begin{array}{l}\text { Defendant driving a car } \\
\text { which resulted in a traffic } \\
\text { accident, which resulted in } \\
\text { another person died }\end{array}$ & 1 (one) person died & $\begin{array}{l}\text { Criminal } \\
\text { imprisonment for } 1 \\
\text { (one) year } 6 \text { months } \\
\text { and a fine of Rp.5 } \\
\text { million, } \\
\text { subsidiary of } 3 \\
\text { months in prison }\end{array}$ \\
\hline
\end{tabular}

Considering the judge's decision above, we must assume that the decision is something that is fair and impartial, this is in line with what is stated in Article 24 of the 1945 Constitution which states; "Judicial power is exercised by a Supreme Court and the Judiciary according to the law". Whereas the explanation of the 1945 Constitution concerning judicial power provides an affirmation,"Judicial Power is an independent power, meaning that it is independent of the influence of Government authority". In this regard, the law must guarantee the position of Judges".

According to Zainal Arifin Hoesein (2016), judicial power is one of the state's powers in the field of law and justice based on Pancasila which is free / independent from interference from parties of extra judicial. Next is the third stage, which is the stage of criminal execution by the first execution apparatus. At this stage the execution apparatus in accordance with Article 270 of the Criminal Procedure Code stipulates that the implementation of court decisions that have legal force will still be carried out by the Prosecutor. For this reason, the court clerk sends a copy of the decision letter to the Prosecutor. In line with the provisions of the Criminal Procedure Code, it is also explained that in Article 36 of Law No. 4 of 2004 concerning Judicial Power, that the implementation of court decisions in criminal cases is carried out by Prosecutors.

In the context of court decisions in road traffic accident cases in accordance with Law Number 22 Year 2009 in article 310 paragraph (1), paragraph (2), paragraph (3) and paragraph (4), the maximum sentence of imprisonment is 6 (six) ) year. Procedure for carrying out court decisions regarding imprisonment or confinement, the Prosecutor receives a copy of the court's decision from the relevant district court clerk within 1 (one) week for ordinary cases and 14 (fourteen) days for cases with a short event, then the Chief Prosecutor issues a letter order to execute the court's decision, then hand the convicted person to the Penitentiary to be imprisoned.

According to Iqrak Sulihin (2016), the aim of imprisonment is not limited to efforts to imprison perpetrators and frighten the public. According to utilitarianism, the aim of imprisonment is as a form of punishment for crimes that lead to rehabilitation or reform efforts. The theory of utilitranism sees imprisonment as a form of punishment that gives good consequences because when undergoing a crime, lawbreakers are kept away from the people, so they are no longer able to commit violations further. According 
to Zimring and Hawkins, as quoted from Iqrak (2016), preventing crime through imprisonment is done by limiting the certainty of individuals in expressing their preferences. This basic aim also influences the principles of imprisonment in many countries. Imprisonment only deprives individuals of their freedom of movement, and imprisonment should not make conditions for prisoners worse than before being convicted.

Based on the above matters, the criminal law policy in the field of road traffic accidents is very strategic in repeating the emergence of road traffic accidents, as well as the fall of futile victims on the highway. The number of death tolls every year is around 30,000, which must be stopped not only through repressive measures, but criminal law policy has great importance. Therefore, it can be said that criminal law policy has an ultimate goal and its main goal is protection for the people, to achieve people's welfare. According to Sudarto as quoted in Barda Nawawi Arief, said that if criminal law is to be involved in overcoming negative aspects of the development to the people / modernization (including crime), then it should be seen in the overall relationship of criminal law policy and this must be an integral part of national development plan.

\section{Conclusions}

The results of writing conducted by the authors in this study, several conclusions that can be submitted are:

1. The issuance of Law Number 22 Year 2009 concerning Traffic and Road Transportation is aimed at realizing traffic services and secure, safe, orderly, smooth transportation services, so as to create a cultured traffic ethic as well as law enforcement and legal certainty for the people.

2. Law Number 22 Year 2009 Concerning Road Traffic and Transport is a product of criminal law policy, which aims to prevent criminal violations, law enforcement, tackling criminal acts and protecting people to achieve social welfare.

3. Criminal law policy has three stages to produce rational forms of law enforcement, namely:

a. Stages of determining the penalty by the legislator;

b. The sentence decision stage, by the court; and;

c. The execution stage of the sentence by the first execution apparatus

d. That criminal law policy has an ultimate goal, and its main goal is protection for the people to achieve people's welfare.

\section{Suggestions}

The results of the writing of this study, the authors provide suggestions as input for relevant parties, namely:
1. Countermeasures, enforcement, and prevention of criminal acts that harm others and the state, are not always determined from the deterrence effect with the threat of punishment and imprisonment, but are determined by how criminal law policies are applied so that they can become rational law enforcement tools.

2. The stages of criminal law policy according to Muladi and Barda Nawawi Arief can be used as a reference by the Government in preparing for the birth of a law with the ultimate goal being law enforcement, legal prevention and legal action.

3. Criminal law policy becomes more effective in creating public order and protecting the people.

4. Future arrangements are needed for people who cause road traffic accidents that have been found guilty by the Court, with the imposition of criminal penalties in the form of providing financial losses to the victim in the amount of cost of living for the victim's family for one year, the amount of which is determined by the Court.

\section{References}

1. Arief, B.N. (2002). Kebijakan Hukum Pidana. Bandung, PT. Citra Aditya Bakti.

2. Hiariej,E.O.S. (2016). Principles of Criminal Law. Yogyakarta: Cahaya Atma Pustaka.

3. Hoesein, Z.A. (2016), Judicial Power in Indonesia, First Matter. Malang, Setara Press.

4. Juwana, H. (2016). Accident Social Security as a Form of State Presence. Jakarta, Spora Consultant.

5. Muladi and Barda Nawawi Arief. (2010), Criminal Theories and Policies. Bandung, PT Alumni.

6. Suhariyono. (2012), Renewal of Fine Penalty in Indonesia, Jakarta: Papas Sinar Sinanti.

7. Sulihin, I. (2016). Punitive Penological Discontinuity, A Genealogical Analysis of Imprisonment. Jakarta, Kencana.

8. Wardana, K.K.W. (2009). Insurance Law, Bandung, Mandar Maju.

\section{Laws/Regulations}

9. The 1945 Constitution of the Republic of Indonesia.

10. Law of the Republic of Indonesia Number 22 of 2009, Regarding Traffic and Road Transportation, Publisher: Ditlantas Babinkam POLRI.

11. Regulation of the Head of the Indonesian National Police Number 15 of 2013 concerning Procedures for Handling Traffic Accidents. 